\title{
Restoring degraded riparian meadows: Biomass and species responses
}

\author{
DAVID W. MARTIN AND JEANNE C. CHAMBERS
}

Authors are doctoral graduate, Program in Ecology, Evolution, and Conservation Biology, University of Nevada, 1000 Valley Road. Reno, Nev. 89512, and research ecologist, USDA Forest Service, Rocky Mountain Research Station. 920 Valley Road. Reno, Nev. 89512.

\section{Abstract}

Riparian meadows in central Nevada are highly productive and have been extensively utilized for livestock grazing. Consequently, many have been severely degraded resulting in changes in species composition and decreases in productivity. During a 3 year study, we examined the responses of mesic meadow systems to yearly nitrogen addition $\left(100 \mathrm{~kg} \mathrm{ha}^{-1}\right)$ and clipping $(8-10 \mathrm{~cm}$ stubble height) to increase our understanding of grazing effects. We also examined the effects of a one-time, fall aeration $(10 \mathrm{~cm}$ deep by $2 \mathrm{~cm}$ wide holes spaced $20 \mathrm{~cm}$ apart) and revegetation (removal of existing vegetation and reseeding) to evaluate the restoration potential of these sites. Changes in total biomass, species aerial cover and frequency, and surface basal cover were used to evaluate treatment responses. Clipping had no effect on total biomass, possibly because it was conducted late in the growing season. In contrast, nitrogen addition plus clipping increased biomass in all 3 years when treatments were compared across sites and for 1 out of 3 years when treatments were compared across a single site. Aeration had no effect on above ground biomass, but has been shown to increase rooting activity in these same meadows. Due to a dry, hot spring, early seral and weedy species had higher establishment than the seeded natives in the revegetation plots, and biomass was low the first year after treatment. Individual species varied in their treatment responses. The cover of low-growing forb species (western aster (Aster occidentalis [Nutt.] Torrey and A. Gray), long-stalk starwort (Stellania Longipes Goldie), and common dandelion (Taraxacum officinale Wigg.) declined through time for all treatments, presumably due to increased grass cover and shading following release from grazing and above average precipitation and water table levels in 1998. Examination of the key graminoids showed that Kentucky bluegrass (Poa pratensis ssp. pratensis L.), an increaser species, did not increase in response to release from grazing, but increased in response to clipping and nitrogen addition. Nebraska sedge (Carex nebrascensis Dewey), a desirable native, increased in response to both release from grazing and nitrogen addition. The results were influenced by high spatial and temporal variability in water table elevations within these systems.

Key Words: Nitrogen addition, clipping, aeration, revegetation, species composition, water tables

The authors thank Terry Nevius, Dave Weixelman, and Desi Zamudio from the Humboldt-Toiyabe National Forest for assistance with this project. Deb Palmquist, USDA-ARS, and Dave Turner, USDA-Forest Service, helped with statistical analyses.

Manuscript accepted 29 Aug. 2000.

\section{Resumen}

Las praderas ribereñas de la parte central de Nevada son altamente productivas $y$ han sido utilizadas extensivamente para el apacentemiento de ganado. Consequentemente, muchas de ellas han sido severamente degradadas resultando en cambios de la composición de especies y la disminución de su productividad. En un estudio de 3 años examinamos las respuestas de los sistemas de praderas mésicas a la adición anual de nitrógeno (100 $\left.\mathrm{kg} \mathrm{ha}^{-1}\right)$ y el corte $(8-10 \mathrm{~cm}$ de altura del rastrojo remanente) para aumentar nuestro entendimiento de los efectos del apacentamiento. También examinamos los efectos de la areación por única vez en otoño (hoyos de $10 \mathrm{~cm}$ de profundidad y $2 \mathrm{~cm}$ de ancho espaciados a $20 \mathrm{~cm}$ ) y la revegetación (remoción de la vegetación existente y resiembra) para evaluar el potencial de rehabilitación de estos sitios. Para evaluar la respuesta a los tratamientos se utilizó los cambios de la biomasa total, cobertura aérea y frecuencia de las especies y la cobertura basal. El corte no tuvo efecto sobre la biomasa total, posiblemente porque se realizó al finales de la estación de crecimiento. En contraste, la adición de nitrógeno mas el corte incrementaron la biomasa en los tres años, esto se observó cuando los tratamientos se compararon entre sitios y en 1 de los 3 años cuando la comparación se realizó en un solo sitio. La aeración no tuvo efecto en la biomasa aérea, pero ha sido demostrado que incrementa la actividad de las raíces de estas praderas. Debido a la primavera seca y caliente, las especies de maleza herbácea y las de etapas serales iniciales tuvieron un mayor establecimiento que las especies nativas sembradas en las parcelas de revegetación y la biomasa fue baja en el primer año después del tratamiento. La respuesta a los tratamientos varió entre especies individuales. La cobertura de especies herbáceas de porte bajo ("Western aster", "Long -stalk starwort" y "Common dendelion") disminuyó a través del tiempo en todos los tratamientos, presumiblemente por el incremento de la cobertura de zacates, el sombreado por la suspensión del apacentamiento y la precipitación arriba del promedio y la elevación del manto fréatico ocurridos en 1998. El examen de las especies clave de gramíneas mostró que el "Kentucky bluegrass" (Poa pratensis ssp. pratensis L.), una especie incresora, no aumento en respuesta a la suspensión del apacentamiento, pero se incrementó en respuesta al corte y la adición de nitrógeno. La especie "Nebraska sedge" (Carex nebrasciensis Dewey), una especie nativa deseable, se incrementó en repuesta tanto a la suspensión del apacentamiento como a la adición de nitrógeno. Los resultados fueron influenciados por la alta variabilidad espacial y temporal de la elevación del manto fréatico dentro de estos sistemas. 
Riparian areas include highly productive, mesic plant communities that serve as the interface between terrestrial and aquatic environments and that are characterized by high levels of biodiversity (Knopf et al. 1988, Schulz and Leininger 1990, Goodwin et al. 1997). Meadow communities are among the most productive components of the riparian corridor (Kauffman and Krueger 1984, Knopf et al. 1988, Chambers 1994, Chambers et al. 1999) and, consequently, often have been degraded by livestock grazing (Kauffman and Krueger 1984, Abel 1989, Clary and Webster 1989, Belsky et al. 1999). Livestock trampling decreases soil macropore spaces resulting in soil compaction, reduced root growth, and lowered plant production (Orr 1960, Laycock and Conrad 1967, Bohn and Buckhouse 1985). Trampling also affects the aerial portions of plants resulting in reduced vegetation height and cover and, thus, altering the microenvironment of the remaining plants (Kobayashi and Nomoto 1997). Nitrogen is deposited in the excreta of the grazing animals, but much of this nitrogen is likely lost through volatilization and leaching (Watson and Lapins 1969, Floate 1970, Woodmansee 1978). In addition, removal of vegetation through grazing may result in a net export of nitrogen from grazed systems. Altered nutrient dynamics can lead to changes in both production and species diversity (Berendse et al. 1992). Thus, livestock grazing can act as a disturbance that alters resource availability and species interactions within riparian meadow systems. This disturbance can have a significant role in restructuring plant communities (Carson and Pickett 1990, Wilson and Tilman 1991).

Little is known about the linkages between severity of degradation and changes in hydrologic regime, soil properties, and vegetation in riparian meadows (Chambers 1994), or about the effects of various land uses or land management activities on these linkages (Richter 1992, Van Haveren et al. 1997). The overall objectives of this study were to increase our understanding of the effects of nitrogen addition and herbage removal on mesic meadows and to evaluate aeration and revegetation as restoration techniques for these ecosystems. The questions addressed were: (1) how do nitrogen addition and herbage removal affect biomass production and dominant species composition within these meadow systems, and (2) can aeration and revegetation be used to increase biomass production and modify species composition?

\section{Methods}

\section{Study area and study sites}

The study area is in the Toiyabe and Toquima Mountain Ranges in central Nevada. Watershed elevations range from about 1,850 to $3,200 \mathrm{~m}$. The nearby town of Austin, Nev. has the only long-term weather data in the region and has mean annual precipitation of $310 \mathrm{~mm}$. Approximately $60 \%$ of the precipitation arrives as winter snow. Peak runoff is during snowmelt in early June, but convective thunderstorms during summer months can contribute significant precipitation. The stream systems are typically located within confined valleys, exhibit steep gradients and are incised (Weixelman et al. 1996). Riparian vegetation consists of quaking aspen (Populus tremuloides Michaux), narrow leaf cottonwood (Populus angustifolia James), river birch (Betula occidentalis Hook), willows (Salix spp.) and meadow communities. Meadow ecosystem types occur along a continuum from high to low water tables. Nebraska sedge (Carex nebrascensis Dewey), a native sedge species, dominates sites that have high water tables ( 0 to $5 \mathrm{~cm}$ from the surface) and Kentucky bluegrass (Poa pratensis ssp. pratensis L.), an increaser species, dominates sites with relatively low water tables $(60 \mathrm{~cm})$. Sites with intermediate water tables $(40$ to $50 \mathrm{~cm}$ ) are codominated by Nebraska sedge and Kentucky bluegrass (Chambers et al. 1999). Other grass and grasslike species that occur along the water table gradient include Baltic rush (Juncus balticus Willd.) and blackcreeper sedge (Carex praegracilis $\mathrm{W}$. Boott), while forbs include western aster (Aster occidentalis [Nutt.] Torrey \& A. Gray), cinquefoil (Potentilla gracilis [Nutt.] S. Watson), and common dandelion (Taraxacum officinale Wigg.) (Weixelman et al. 1996, Castelli et al. 2000). These ecosystems have been grazed by livestock since European settlers colonized the area.

During the summer of 1995, suitable meadow sites $(n=3)$ were identified in the Austin Ranger District of the HumboltToiyabe National Forest, Nev. Meadows were selected with dominant species composition (approximately 10\% Nebraska sedge and $40 \%$ Kentucky bluegrass) and water table depths (40 to $60 \mathrm{~cm}$ ) typical of the mesic meadow ecosystem type in central Nevada (Weixelman et al. 1996). The selected sites include Corral Canyon $\left(39^{\circ} 7^{\prime} 13.5^{\prime \prime} \mathrm{N}, 116^{\circ} 48^{\prime} 38.6^{\prime \prime} \mathrm{W}\right)$ in the Toquima Mountain Range, and Cahill Canyon $\left(39^{\circ} 27^{\prime} 57.6^{\prime \prime} \mathrm{N}, 117^{\circ} 2^{\prime} 0.4^{\prime \prime} \mathrm{W}\right)$ and Emigrant Canyon (39 30'35.4" N, $\left.117^{\circ} 1^{\prime} 5.9^{\prime \prime} \mathrm{W}\right)$ in the Toiyabe Mountain Range. All 3 sites are located in trough drainageways. Soil characteristics are typical of these ecosystems (Chambers et al. 1999). Cahill Canyon (elevation 2,325 m) and Emigrant Canyon (elevation 2,174 m) have soils that are aquic cryoborolls. Corral Canyon (elevation 2,358 m) has soils that range from aquic cryoborolls to cryaquolls.

\section{Study design}

The study design was a completely randomized block. One block (replicate) was located within each of the 3 study sites (Corral, Emigrant, and Cahill) to examine treatment differences across sites. Three additional blocks (replicates) were placed at 1 site (Corral) to evaluate differences across a single site. Study treatments consisted of a control, nitrogen addition, clipping, aeration, and revegetation. Clipping was imposed over the nitrogen, aeration, and revegetation treatments bringing the total number of treatments to 8 . At each site, blocks were located in areas that appeared homogeneous in terms of vegetation, soils, and depth to water table. Block sizes were not uniform due to the small size and heterogeneity of these meadows and ranged from $16 \times 16$ to $25 \times 25 \mathrm{~m}$ and treatment plots from $4 \times 4$ to $5 \times 5 \mathrm{~m}$. Fences designed to exclude livestock were constructed around the blocks at each site. A standard $30 \mathrm{~cm}$ diameter rain gage was placed near the blocks. A series of wells (7 to 9) were located within each block using perforated PVC pipe (10 $\mathrm{cm}$ in diameter) that extended into the water table.

\section{Treatments}

Aeration was done in the fall of 1995 using an electric drill equipped with a 2 cm diameter, power ship auger to drill into the soil. Holes were uniformly spaced at $20 \mathrm{~cm}$ intervals to a depth of $30 \mathrm{~cm}$. Aeration has been shown to eliminate the effects of subsurface compaction in forested systems (Nambiar and Sands 1992). The aeration treatment should have penetrated the compacted layer of the soil allowing water to infiltrate and through natural freeze/thaw processes to break up the compacted soil layer.

Nitrogen addition consisted of a hand application of sulfur coated urea (36-0-0), a slow release nitrogen fertilizer, at a rate of $100 \mathrm{~kg} \mathrm{ha}^{-1}$ repeated in fall 1995, 1996, and 1997. This type of fertilizer and application rate have been shown to increase both above and below ground production and disease resistance in both Nebraska 
sedge and Kentucky bluegrass (Davis and Doenoeden 1991, Thompson and Clark 1993, Reece et al. 1994).

The revegetation treatment started with killing all existing vegetation using a short-lived herbicide (Round-up ${ }^{\circledR}$ ). The soil was then tilled with a commercial grade roto-tiller to break up the sod, and allow for removal of dead plant material. Six species native to central Nevada riparian meadows, slenderbeaked sedge (Carex athrostachya Olney), Nebraska sedge, blackcreeper sedge, tufted hairgrass (Deschampsia cespitosa [L.] Beauv.), carpet clover (Trifolium monanthum A. Gray), and cow clover ( $T$. wormskjoldii Lehm.) were selected for seeding based on their abundance in similar meadows with higher water tables. Seeds were collected adjacent to the study areas, cleaned and tested for viability. Seeding was conducted in the fall of 1995 at a rate of 150 viable seeds $\mathrm{m}^{-2}$ for all species except cow clover, which was seeded at a rate of 125 seed $\mathrm{m}^{-2}$ due to the limited number of seeds collected. Straw mulch blankets (5 $\mathrm{cm}$ thick, Granite Seed Co.) were placed over the seeded areas to aid seed germination, improve soil moisture retention, and insure that the seeds and topsoil were not blown away.

The clipping treatment, applied alone as a treatment and in combination with each of the other treatments, consisted of trimming the above ground vegetation biomass with a power trimmer to a stubble height of between 8 and $10 \mathrm{~cm}$. This removed approximately 50 to $75 \%$ of the aboveground biomass of both Nebraska sedge and Kentucky bluegrass. Clipping was conducted once a year in late July and the clippings were subsequently removed from the plot. This timing and level were used to simulate the grazing activity that is normally prescribed for these sites.

\section{Vegetative response}

Five, $0.1 \mathrm{~m}^{2}$ quadrats were randomly located within each treatment plot. Ten quadrats were also randomly placed outside the exclosures at each site. At peak production (late July), and immediately prior to the clipping treatment, frequency and percent aerial cover by species, were recorded for the vegetation in each quadrat. Frequency was assessed with a nested frequency frame and percent aerial cover was visually assessed in 12 classes: $<1 ; 1$ to $5 ; 6$ to $15 ; 16$ to $25 ; 26$ to $35 ; 36$ to $45 ; 46$ to $55 ; 56$ to $65 ; 66$ to $75 ; 76$ to $85 ; 86$ to $95 ; 96$ to $100 \%$. Prior to sampling, basal cover by category was determined using a point frame. Cover cate-
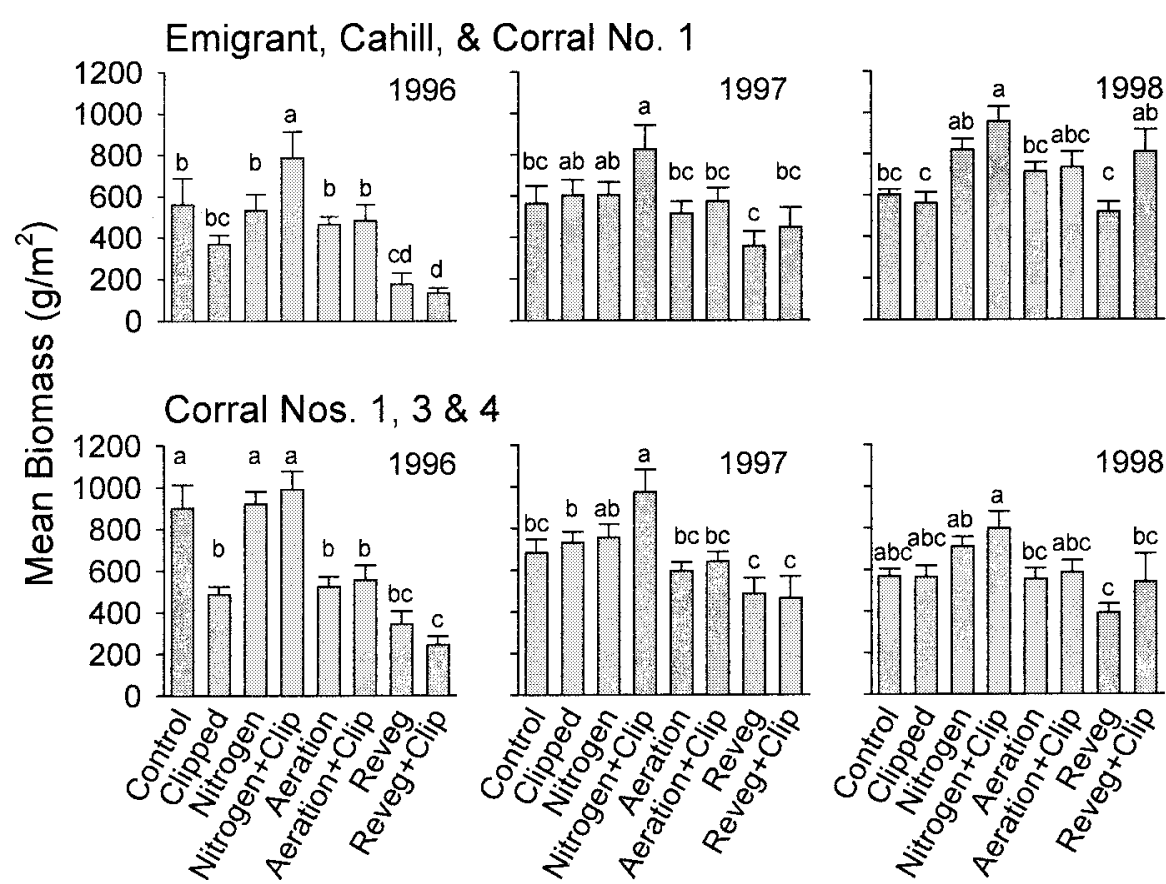

Fig. 1. Mean biomass (+ S.E.) during the study period for both the across site comparison (Emigrant, Cahill and Corral \#1) and the single site comparison (Corral \#1, \#3, and \#4). Unlike letters indicate differences among treatments within individual years $(P \leq 0.05)$.

gories included bare ground, litter, and vegetation by species. Standing crop biomass was determined by clipping the quadrats to ground level. Samples were oven dried at $60^{\circ} \mathrm{C}$ for 72 hours for dry weight determination.

\section{Statistical analysis}

Two factor (treatment and year) repeated measures analysis of variance with repeated measures on year were used to examine differences in biomass, aerial cover, and basal cover. The sites served as blocks to examine treatment differences across sites. The 3 blocks in Corral (Corral \#1, Corral \#3, and Corral \#4) were used to evaluate differences within a single site. Aerial cover data were pooled from the main effect treatment plots (control, clipped, nitrogen and aeration) at Corral Canyon for 6 of the dominant species for 1996 and 1998. Pooled data were analyzed with a 2 factor (treatment and year) repeated measures analysis of variance. Mean comparisons were performed using Fisher's Protected LSD (Steel and Torrie 1980). Site similarity was determined with the Bray-Curtis Similarity Index on both the species frequency and aerial cover data. Comparisons were also conducted using Spearman's Rank Order Correlation analysis of both species frequency and aerial cover (Zar 1999). The Spearman's rank order correlation coefficient provides a non-parametric statistical measure of the similarity of 2 areas as reflected by the relative importance of the various species within the sampled areas (Chambers 1983).

\section{Results}

\section{Biomass response}

Significant differences in biomass existed among treatments for the across site comparison $\left(\mathrm{F}_{7,14}=4.54, \mathrm{P}=0.0078\right)$ and for the single site comparison $\left(\mathrm{F}_{7,14}=\right.$ $5.77, \mathrm{P}=0.0027$ ). For the across site comparison, the nitrogen plus clipping treatment had greater biomass than the control for all 3 years (Fig. 1). This treatment also had greater biomass in the single site comparison in 1997. Nitrogen alone was marginally significant during 1998 for the across site comparison $(\mathrm{P}=0.0579)$ and for the single site comparison $(\mathrm{P}=0.0603)$. In 1996, biomass in the revegetation treatments was lower than in the controls for both sets of replicates (Fig. 1). These differences did not persist beyond the first year. There were no differences between the controls and either the clipped or aeration treatments for either comparison.

There was a year by site interaction for the across site comparison $\left(\mathrm{F}_{4,28}=4.95, \mathrm{P}\right.$ $=0.0038)$ and for the single site compari- 
son $\left(\mathrm{F}_{4,28}=3.40, \mathrm{P}=0.0219\right)$. In general, biomass at all sites was lowest in 1996 and highest in 1998. Emigrant had lower biomass than the other sites in all 3 years, and Cahill had lower biomass than Corral in 1996.

\section{Aerial and basal cover}

Total aerial cover consistently ranged from 70 to $80 \%$ across these meadows. Consequently, aerial cover did not differ among either sites or treatments. Also, there were few significant differences in total basal cover between sites or treatments.

\section{Revegetation success}

Establishment of the seeded species in the revegetation treatment plots was very limited. Both blackcreeper sedge and Nebraska sedge occurred in the revegetation plots at Cahill Canyon in 1996, but they did not occur in either 1997 or 1998 or on the Emigrant revegetation plots. Nebraska sedge and blackcreeper sedge were present also in the Corral blocks in 1996, but only Nebraska sedge was found in 1998. Meadow barley (Hordeum brachyantherum Nevski) dominated the revegetation plots at all sites. Cover values were between 30 and $50 \%$ at all sites by 1998. Other species that were abundant on the revegetation plots were curley dock (Rumex crispus L.), elk thistle (Cirsium drummondii Torrey \& A. Gray), common dandelion, desert goosefoot (Chenopodium dessicatum Nelson), and water montia (Montia chamissoi [Ledeb.] Robins \& Fern.). Because of the differences in

Table 1. Bray-Curtis similarity indices of frequency (B-C freq) and cover (B-C cov) and Spearmans rank sum correlation of frequency (Sper freq) and cover (Sper cov) for the control plots at Corral \#1, Cahill and Emigrant and at Corral \#1, Corral \#3, and Corral \#4 in 1996 and 1998. An (*) indicates a significant positive correlation at the 0.05 level. An (+) indicates significance at 0.10 .

\begin{tabular}{|c|c|c|c|c|c|c|c|c|}
\hline & \multicolumn{4}{|c|}{ Corral \#1 } & \multicolumn{4}{|c|}{ CaHill } \\
\hline & $\begin{array}{l}\text { B-C } \\
\text { Freq }\end{array}$ & $\begin{array}{l}\text { Sper } \\
\text { Freq. }\end{array}$ & $\begin{array}{l}\text { B-C } \\
\text { Cov }\end{array}$ & $\begin{array}{c}\text { Sper } \\
\text { Cov }\end{array}$ & $\begin{array}{l}\text { B-C } \\
\text { Freq }\end{array}$ & $\begin{array}{l}\text { Sper } \\
\text { Freq }\end{array}$ & $\begin{array}{l}\text { B-C } \\
\text { Cov }\end{array}$ & $\begin{array}{l}\text { Sper } \\
\text { Cov }\end{array}$ \\
\hline \multicolumn{9}{|l|}{1996} \\
\hline Cahill 42 & 0.27 & 27 & 0.59 & & & & & \\
\hline Emigrant & 61 & $0.53 *$ & 25 & $0.44 *$ & 35 & 0.25 & 23 & 0.35 \\
\hline \multicolumn{9}{|l|}{1998} \\
\hline Cahill & 44 & $0.47 *$ & 27 & $0.41 *$ & & & & \\
\hline \multirow[t]{4}{*}{ Emigrant } & 43 & 0.28 & 30 & 0.28 & 59 & $0.51 *$ & 700 & $48^{*}$ \\
\hline & \multicolumn{4}{|c|}{ "Corral \#1 } & \multicolumn{4}{|c|}{ CaHill } \\
\hline & B-C & Sper & B-C & Sper & B-C & Sper & B-C & Sper \\
\hline & Freq & Freq. & $\mathrm{Cov}$ & Cov & Freq & Freq & Cov & Cov \\
\hline \multicolumn{9}{|l|}{$\overline{1996}$} \\
\hline Corral \#3 & 50 & $0.60 *$ & 24 & $0.69 *$ & & & & \\
\hline Corral \#4 & 54 & $0.55^{*}$ & 48 & $0.59 *$ & 64 & 0.19 & 30 & $0.37+$ \\
\hline \multicolumn{9}{|l|}{1998} \\
\hline Corral \#3 & 40 & $0.64 *$ & 25 & 0.17 & & & & \\
\hline Corral \#4 & 60 & $0.73 *$ & 59 & $0.46^{*}$ & 72 & $0.84^{*}$ & 36 & $0.57 *$ \\
\hline
\end{tabular}

The Bray-Curtis Similarity Index ranged from 50 to 64 for species frequency and between 24 and 48 for species cover in 1996. In 1998, the range was between 40 and 72 for species frequency and 25 to 59 for species cover. Further, the Spearman's Rank Sum Correlations indicated that there were significant positive correlations between the blocks for both species frequency and cover.

To examine potential treatment effects on cover of individual species, data from the Corral Canyon blocks were pooled. The clipping plus aeration and clipping plus nitrogen treatments were dropped from the comparisons because previous analysis indicated there were very few differences between these plots and the main effect plots. Cover of the forb species tended to decrease between 1996 and 1998 in all treatment plots, although the differences were not always significant (Table 2). Western aster decreased significantly in both the clipped and nitrogen plots. Longstalk starwort decreased significantly in the control, nitrogen and grazed plots, while dandelion decreased significantly in the control, clipped, aerated, and grazed plots. The responses of the grass and grasslike species to the different treatment were largely opposite to those of the forbs (Table 2). Nebraska sedge nearly doubled its cover in the control and in the nitrogen addition plots. Cover of meadow barley also doubled with nitrogen addition. Kentucky bluegrass increased in response to all treatments but did not increase in the control plots. With clipping, Kentucky bluegrass exhibited a 4-fold increase in cover, while its cover doubled in the unexclosed area. Increases with nitrogen and aeration were not as dramatic, but cover values still increased by $50 \%$.

\section{Environmental variables}

Precipitation amounts varied between sites, seasons, and years (Table 3). As expected for Great Basin ecosystems, most precipitation fell during the winter months. The Corral Canyon site received the least precipitation and the Emigrant site the most. Precipitation amounts in 1997 were much lower than 1998 while 1996 was intermediate for all sites. Precipitation data for 1997 at Cahill Canyon was questionable and therefore not reported. It was likely similar to that of Emigrant Canyon.

Depth to water table was spatially and temporally variable as illustrated by the Corral Canyon and Cahill blocks (Fig. 2). There were seasonal declines in water table depth for all blocks with the degree 
Table 2. Mean cover (SE) for 1996 and 1998 and the ratio of the 1998/1996 cover values for 6 of the dominant species. Data for the Corral Canyon blocks (\#1, \#3, and \#4) were pooled for the analysis. Significant differences for each treatment through time are indicated by a (+) for an increase and a (-) for a decrease.

\begin{tabular}{|c|c|c|c|c|c|c|}
\hline $\begin{array}{l}\text { Treatment } \\
\text { Year }\end{array}$ & $\begin{array}{c}\text { Aster } \\
\text { occidentalis }\end{array}$ & $\begin{array}{c}\text { Carex } \\
\text { nebrascensis }\end{array}$ & $\begin{array}{c}\text { Hordeum } \\
\text { brachyantherum }\end{array}$ & $\begin{array}{c}\text { Poa } \\
\text { pratensis }\end{array}$ & $\begin{array}{l}\text { Stellaria } \\
\text { longipes }\end{array}$ & $\begin{array}{c}\text { Taraxacum } \\
\text { officinale }\end{array}$ \\
\hline $\begin{array}{l}\text { Control } \\
1996 \\
1998 \\
1996 / 1998\end{array}$ & $\begin{array}{l}3.9(1.4) \\
3.5(1.3) \\
0.9\end{array}$ & $\begin{array}{l}14.5(4.0) \\
29.8(3.8)+ \\
2.1\end{array}$ & $\begin{array}{l}3.3(2.4) \\
8.2(2.4)+ \\
2.5\end{array}$ & $\begin{array}{l}16.4(3.2) \\
18.5(3.2) \\
1.1\end{array}$ & $\begin{array}{l}13.9(1.6) \\
1.0(1.6)- \\
0.1\end{array}$ & $\begin{array}{l}6.9(1.7) \\
1.2(1.8)- \\
0.2\end{array}$ \\
\hline $\begin{array}{l}\text { Clipped } \\
1996 \\
1998 \\
1996 / 1998\end{array}$ & $\begin{array}{l}9.4(1.3) \\
4.5(1.3)- \\
0.5\end{array}$ & $\begin{array}{l}8.9(3.5) \\
9.3(3.6) \\
1\end{array}$ & $\begin{array}{l}1.1(2.9) \\
6.5(2.4)+ \\
5.9\end{array}$ & $\begin{array}{l}4.9(3.2) \\
21.4(3.2)+ \\
4.4\end{array}$ & $\begin{array}{l}2.0(1.4) \\
0.9(1.4) \\
0.5\end{array}$ & $\begin{array}{l}8.8(1.4) \\
2.9(1.6)- \\
0.3\end{array}$ \\
\hline $\begin{array}{l}\text { Nitrogen } \\
1996 \\
1998 \\
1996 / 1998\end{array}$ & $\begin{array}{l}8.9(1.3) \\
3.2(1.4)- \\
0.4\end{array}$ & $\begin{array}{l}20.0(3.5) \\
39.9(3.8)+ \\
2\end{array}$ & $\begin{array}{l}5.2(1.6) \\
10.1(1.7)+ \\
1.9\end{array}$ & $\begin{array}{l}9.8(3.2) \\
15.8(3.8)+ \\
1.6\end{array}$ & $\begin{array}{l}7.7(1.3) \\
3.3(1.5)- \\
0.4\end{array}$ & $\begin{array}{l}9.3(1.5) \\
8.2(1.9) \\
0.9\end{array}$ \\
\hline $\begin{array}{l}\text { Aeration } \\
1996 \\
1998 \\
1996 / 1998\end{array}$ & $\begin{array}{l}7.5(1.3) \\
5.3(1.3) \\
0.7\end{array}$ & $\begin{array}{l}10.5(3.7) \\
13.5(3.5) \\
1.3\end{array}$ & $\begin{array}{l}5.2(1.6) \\
6.3(1.7) \\
1.2\end{array}$ & $\begin{array}{l}8.1(3.3) \\
18.0(3.2)+ \\
2.2\end{array}$ & $\begin{array}{l}3.6(1.4) \\
3.3(1.4) \\
0.9\end{array}$ & $\begin{array}{l}9.5(1.6) \\
2.5(1.9)- \\
0.3\end{array}$ \\
\hline $\begin{array}{l}\text { Unexclosed } \\
1996 \\
1998 \\
1996 / 1998\end{array}$ & $\begin{array}{l}5.5(1.9) \\
3.1(1.8) \\
0.6\end{array}$ & $\begin{array}{l}5.9(6.6) \\
7.5(7.0) \\
1.3\end{array}$ & $\begin{array}{l}4.0(2.0) \\
6.3(2.2) \\
1.6\end{array}$ & $\begin{array}{l}13.8(4.6) \\
28.5(4.6)+ \\
2.1\end{array}$ & $\begin{array}{l}7.0(2.4) \\
0.1(0.6)- \\
0\end{array}$ & $\begin{array}{l}12.6(2.5) \\
4.5(2.3)- \\
0.4\end{array}$ \\
\hline
\end{tabular}

of spring recharge depending on the amount of overwinter precipitation. In 1998, the year with the most overwinter precipitation, spring recharge was greater than in either 1996 or 1997 , with water table levels at or near the surface of all blocks for a large portion of the growing season. Seasonal differences varied among blocks. For example, during the 1996 growing season, the water table decline for both the Cahill and Emigrant Canyon blocks was greater than $1 \mathrm{~m}$, and by the end of the 1997 growing season, the water table depth at Emigrant Canyon was nearly $2 \mathrm{~m}$. However, throughout the 1998 growing season there was running water flowing at depths up to $10 \mathrm{~cm}$ over most of the Emigrant block. In contrast, the Corral \#3 block exhibited only a $22 \mathrm{~cm}$ difference in average water table between May and August 1996, and a $34 \mathrm{~cm}$ difference between May and August 1998 (Fig. 2).

The factor that likely had the greatest impact on the study was the range in water table depths found across each block for a particular sampling period. The greatest range in water table depth was observed at Cahill Canyon with a difference of over 1 $\mathrm{m}$ being common across the $16 \times 16 \mathrm{~m}$ block. Corral \#1 also exhibited high levels of variability with differences as great as $60 \mathrm{~cm}$ found between wells only $10 \mathrm{~m}$ apart. The least variable blocks were Corral \#3, Corral \#4 and Emigrant. This high level of spatial variability was not apparent at the time of site selection in August of 1995. However, the 3 years of al. 1999, Castelli et al. 2000), and water table depth undoubtedly influenced the study results. Despite an attempt to select study sites with similar water tables and species composition, high levels of spatial and temporal variability were observed during the 3-yr study. The confounding effects of temporal and spatial variability in the water table are illustrated by the biomass response at Emigrant and Corral Canyons. At Emigrant, biomass in 1998, the wettest year, was nearly double that of the 1996 biomass for all treatment plots. At Corral \#1, the control plot consistently had the highest water table and, during both 1996 and 1997 which were dry years, it had the greatest biomass. In contrast, during 1998 there was standing water on this plot throughout the growing season and biomass was significantly lower than in 1996.

The high spatial and temporal variability of the water table provides important lessons for designing studies to evaluate structural and functional processes in similar types of meadows. In most cases, water table depth should be treated as a covariate when evaluating treatment effects on plant response variables such as biomass. Also, depending on study design, a high number of blocks or larger blocks with multiple randomly located treatment plots should be used to adequately account for the high spatial variability. Finally, sampling should be conducted over relatively long time periods (3-5 yr) to account for the temporal variability.

Few treatment effects on biomass were observed in our central Nevada meadows. Clipping had little or no effect on biomass in comparison to the control. These results are consistent with those of a similar study that indicated defoliation to a $10 \mathrm{~cm}$ stubble height did not significantly affect biomass production (Clary 1995). Also, the 1975, Heady and Zinke 1978, Allen-Dic

Table 3. Precipitation amounts at each study location for the 3 years of the study. Overwinter is from October to May and growing season is from June to September.

\begin{tabular}{llccc}
\hline \hline \multirow{2}{*}{ Site } & & \multicolumn{3}{c}{ Year } \\
\cline { 3 - 4 } Corral & Period & 1996 & 1997 & 1998 \\
\hline & & & & \\
& & & 60 & 280 \\
& Overwinter & 200 & 30 & 110 \\
Cahill & Growing season & 110 & 90 & 390 \\
& Total & 310 & - & 460 \\
& Overwinter & & - & 20 \\
Emigrant & Growing season & 290 & - & 480 \\
& Total & 60 & 180 & 590 \\
& Overwinter & 350 & 240 & 50 \\
& Growing season & & 420 & 640 \\
\hline
\end{tabular}



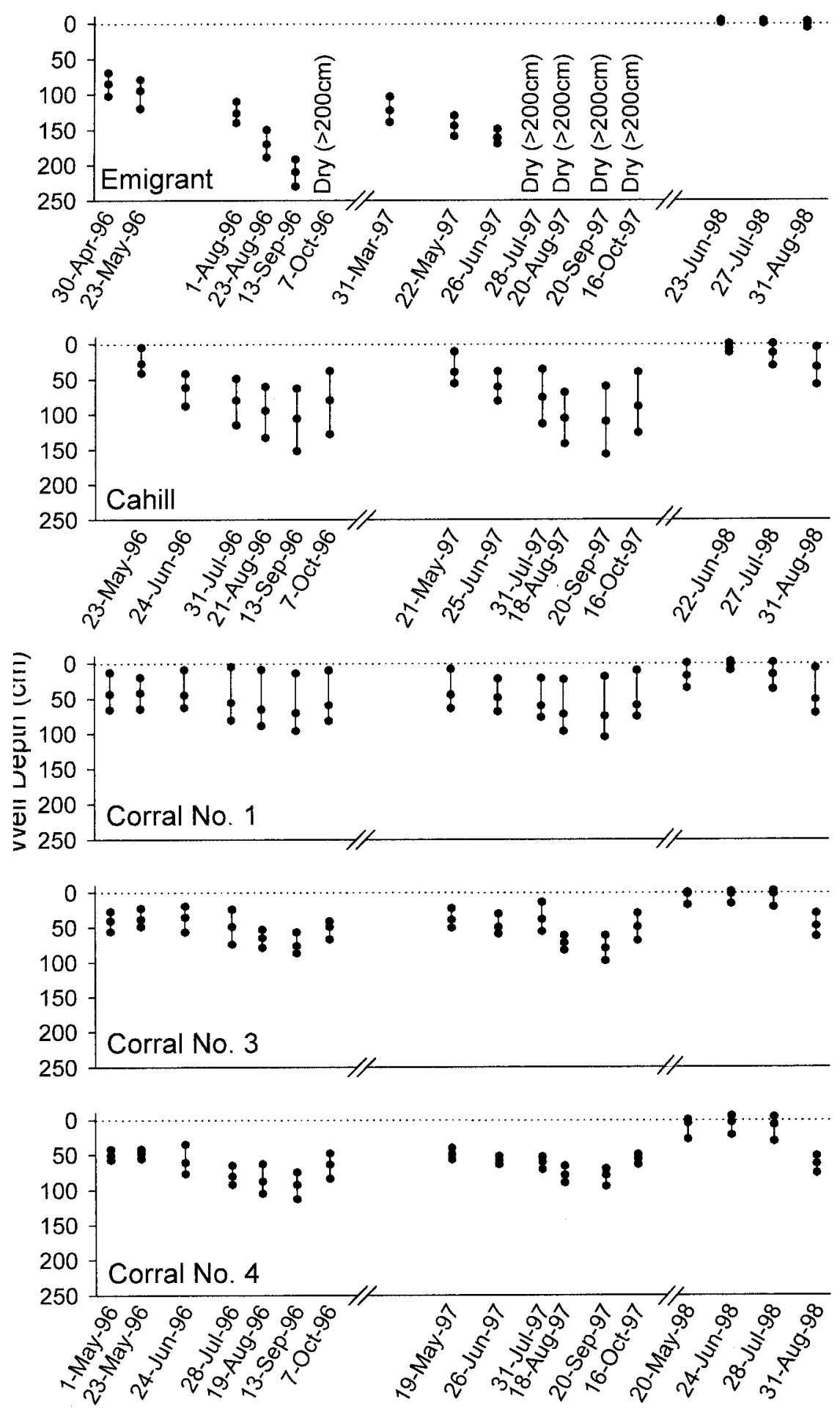

Fig. 2. Water table depths for Emigrant, Cahill and Corral for 1996, 1997, and 1998. Mean water table depth for each sampling period is indicated by the circle at the center of the line. The top of each line indicates the minimum depth to the water table within a study plot at a particular sampling time; the bottom indicates the maximum depth.

lack of a significant effect may have been related to the timing of the treatment. In the current study, clipping did not occur until late in the growing season after plants had already begun to senesce.

Nitrogen addition was the only treatment that resulted in an increase in above ground biomass relative to the control.
Nitrogen plus clipping had a significant effect during all 3 years for the across site comparison and during 1997 for the within site comparison. Nitrogen alone was marginally significant during 1998 for both comparisons. The greater response on clipped plots was likely the result of higher contact of the fertilizer granules with the exposed soils, warmer soil temperatures and, thus, higher and more rapid nitrogen uptake. In general, phenological development of the plants on the nitrogen addition plots was accelerated. At the Corral Canyon plots, plants matured and began to senesce 2 to 4 weeks earlier on the nitrogen addition plots than on the other treatment plots. This type of accelerated development may reduce the efficiency of biomass or fruit production as a result of seasonal growth reduction (Lambers et al.1998). Further, nitrogen addition can decrease root:shoot ratios in wetlands (Shaver and Melillo 1984) and was observed to decrease rooting activity in these central Nevada meadows (Martin 1999). Thus, the effect of added nitrogen, either as a fertilizer or as cow urine and dung, may be detrimental.

Although there was not a large effect on above ground biomass in response to aeration, the lack of an above ground response may be misleading. There was an increase in rooting activity in aerated plots, especially at Emigrant Canyon (Martin 1999), and total biomass may have increased with aeration. Aeration can reverse the negative effects of livestock trampling, including reduced root growth and lower plant production, when subsurface compaction is reduced or eliminated (Orr 1960, Laycock and Conrad 1967, Bohn and Buckhouse 1985).

Success of the revegetation treatment was limited due to constraints on the establishment of the seeded native species and competition with early seral and weedy species. The lack of significant establishment of the seeded species was likely due to the adverse conditions that existed on the revegetation plots during the dry spring of 1996. The surfaces of these dark meadow soils dried rapidly and were warmer than vegetated surfaces. Establishment of early seral or weedy species probably further decreased emergence and survival of the seeded species.

Individual species responses were related to life form. Between 1996 and 1998, there was a decrease in the aerial cover of all 3 forb species in all plots. This may be related to the differences in environmental variables between the 2 sampling years and to an increase in competition from grasses and grass-like species following 
release from grazing. There was considerably more precipitation in 1998 than in 1996 and 1997. Consequently, the water table was much higher during the 1998 growing season and there was standing water on most of the Corral Canyon plots throughout the summer. Lower growth forms would have been submerged for extended periods. Also, the increased height of grasses and grasslike species within the exclosed plots may have reduced light to underlying forbs resulting in lower forb cover and decreased richness (Carson and Pickett 1990, Wilson and Tilman 1991, Kobayashi and Nomoto 1997).

Kentucky bluegrass, an increaser grass, exhibited an increase in cover in the clipped, aerated, nitrogen addition, and grazed treatments between 1996 and 1998. Its cover did not change on the control plots. These results are consistent with field observations indicating that Kentucky bluegrass significantly increases in cover in grazed riparian meadows, while no cover increases and even decreases occur in sites excluded from grazing (Schultz and Leininger 1990, Green and Kaufmann 1995).

Nebraska sedge exhibited an increase in cover in both the nitrogen addition and control plots. These results contrast with findings that grazing had no effect on shoot frequency and density (Ratliff and Westfall 1987) or cover (Schulz and Leininger 1990) of Nebraska sedge. Our data indicate that Nebraska sedge may exhibit significant increases in aerial cover when released from grazing. However, it is important to note that the relative abundance of both Kentucky bluegrass and Nebraska sedge also depends on seasonal and temporal variability in water table depth. Tiller number and above ground biomass of Nebraska sedge increase in response to locally or seasonally higher water tables, while tiller number and biomass of Kentucky bluegrass decrease under the same conditions (Martin 1999).

These results illustrate the complexity of the factors structuring riparian meadow communities and influencing their restoration. Water table plays a critical role in the functional processes within riparian meadow systems and in determining their recovery potentials. In the absence of grazing, portions of meadows with higher water tables may exhibit a shift in dominance from Kentucky bluegrass to Nebraska sedge. Also, the number or abundance of forb species in these meadows may decline in the absence of grazing regardless of water table (but see Stohlgren et al. 1999). Late season herbage removal may not have a significant effect on biomass, because many species have already begun to senesce. Other aspects of grazing, such as nitrogen deposition, may significantly increase biomass production, but decrease rooting activity, and alter plant phenology and species composition. These effects may actually decrease system resilience to disturbance and reduce longer-term productivity.

The study indicates that aeration may be an effective restoration treatment for decreasing or eliminating compaction due to livestock trampling. Aeration does not affect species composition or above ground biomass within these meadows in the short-term, but increases in rooting activity (Martin 1999) may ultimately influence both species composition and aboveground productivity. Similar to other ecosystem types, revegetation of meadows with desirable native species requires favorable weather conditions for seed germination and seedling survival. Thus, the potential for restoring entire communities using revegetation may be limited due to constraints on establishment especially during dry years.

\section{Literature Cited}

Abel, D. L. (Coordinator). 1989. Proc. California Riparian Systems Conf. Davis, Calif. USDA For Serv. PSW For. Range Exp. Sta. Gen. Tech. Rep. PSW-110.

Allen-Diaz, B. H. 1991. Water table and plant species relationships in Sierra Nevada meadows. Amer. Midland Natur. 126:30-43.

Belsky, A. J., A. Matzke, and S. Uselman. 1999. Survey of livestock influences on stream and riparian ecosystems in the western United States. J. Soil and Water Conserv. 54:419-431.

Berendse, F., M. J. M. Oomes, H. J. Altena, and W. Th. Elberse. 1992. Experiments on the restoration of species-rich meadows in The Netherlands. Biol. Conserv. 62:59-65.

Bohn, C. C. and J. C. Buckhouse. 1985. Some responses of riparian soils to grazing management in northeastern Oregon. J. Range Manage. 38:378-381.

Carson, W. P. and S. T. A. Pickett. 1990. Role of resources and disturbance in the organization of an old-field plant community. Ecol. 71:226-238.

Castelli, R. M., J. C. Chambers, and R. J. Tausch. 2000. Soil-plant relations along a soil-water gradient in Great Basin riparian meadows. Wetlands 20:251-266.

Chambers, J. C. 1983. Measuring species diversity on revegetated surface mines: An evaluation of techniques. USDA For. Serv, Res. Paper INT-322. Ogden, Ut.
Chambers, J. C. 1994. Maintaining and restoring riparian ecosystem integrity in central Nevada: An interdisciplinary ecosystem management project. In: Northwest regional riparian symposium "Diverse values: Seeking common ground". Boise, Ida.

Chambers, J. C., D. C. Zamudio, R. R. Blank, and R. J. Tausch. 1999. Soil properties of central Nevada riparian areas: I. Meadow ecosystem types. J. Range Manage. 52:92-99.

Clary, W. P. 1995. Vegetation and soil responses to grazing simulation on riparian meadows. J. Range Manage. 48:18-25.

Clary, W.P. and B.F. Webster. 1989. Managing grazing of riparian areas in the Intermountain region. USDA For. Serv. Gen. Tech. Rep. INT-263. Ogden, Ut.

Davis, D. B. and P. H. Dernoeden. 1991. Summer patch and Kentucky Bluegrass quality as influenced by cultural practices. Agron. J. 83:670-677.

Floate, M. J. S. 1970. Decomposition of organic materials from hill soils and pastures II. Comparative studies on the mineralization of carbon, nitrogen, and phosphorus and plant materials, and sheep faeces. Soil Biol. Biochem. 2:173-185.

Green, D.M. and J.B. Kaufmann. 1995. Succession and livestock grazing in a northeastern Oregon riparian ecosystem. J. Range Manage. 48:307-313.

Goodwin, C. N., C. P. Hawkins, and J. L. Kersher. 1997. Riparian Restoration in the Western United States: Overview and perspective. Restoration Ecol. 5:4-14.

Heady, H.F. and P.J. Zinke. 1978. Vegetational changes in Yosemite Valley. U.S. Nat. Park Serv. (Occas). Pap. \#5. Washington, D.C.

Kauffman, J. B. and W. C. Krueger. 1984. Livestock impacts on riparian ecosystems and streamside management implications... a review. J. Range Manage. 37:430-438.

Kobayashi, T., Y. Hori, and N. Nomoto. 1997. Effects of trampling and vegetation removal on species diversity and micro-environment under different shade conditions. J. Veg. Sci. 8:873-880.

Knopf, F.L., R.R. Johnson, T. Rich, F.B. Samson, and R.C. Szaro. 1988. Conservation of riparian ecosystems in the United States. Wilson Bull. 100:272-284.

Lambers, H., F. S. Chapin III, and T. L. Pons. 1998. Plant physiological ecology. Springer-Verlag. New York, N.Y.

Laycock, W. A. and P. W. Conrad. 1967. Effect of grazing on soil compaction as measured by bulk density on a high elevation cattle range. J. Range Manage. 20:136-140.

Martin, D. W. 1999. Species interactions and recovery potentials of Nevada sedge/Kentucky bluegrass meadows in central Nevada. Ph.D. Diss. Univ. Nevada. Reno, Nev.

Nambiar E.K.S. and R. Sands. 1992. Effects of compaction and simulated root channels on the subsoil on root development, water uptake, and growth of radiata pine. Tree Physiol. 10:297-306. 
Orr, H. K. 1960. Soil porosity and bulk density on grazed and protected bluegrass range in the Black Hills. J. Range Manage. 13:80-86.

Ratliff, R.D. and S.E. Westfall. 1987. Dryyear grazing and Nebraska sedge (Carex nebraskensis). Great Basin Natur. 47:422-426.

Reece, P. E., J. T. Nichols, J. E. Brummer, R.K. Engel, and K. M. Eskridge. 1994. Harvest date and fertilizer effects on native and interseeded wetland meadows. J. Range Manage. 47:178-183.

Richter, H. E. 1992. Development of a conceptual model for floodplain restoration in a desert riparian system. Arid Lands Newsletter 32:13-17.

Schulz, T. T. and W.C. Leininger. 1990. Differences in riparian vegetation structure between grazed areas and exclosures. J. Range Manage. 43:295-298.

Shaver, G.R. and J. M. Melillo. 1984. Nutrient budgets of marsh plants: efficiency concepts and relation to availability. Ecol 65:1491-1510.
Steel, R. G. D. and J. H. Torrie. 1980. Principles and procedures of statistics $\left(2^{\text {nd }}\right.$ ed). McGraw-Hill Book Co., New York, N.Y.

Stohlgren, T. J., L. D. Schell, and B. Vanden Heuvel. 1999. How grazing and soil quality affect native and exotic plant diversity in Rocky Mountain grasslands. Ecol. Appl. 9:45-64.

Stromberg, J.C., R. Tiller, and B. Richter. 1996. Effects of groundwater decline on riparian vegetation of semiarid regions: The San Pedro, Arizona. Ecol. Appl. 6:113-131.

Thompson, D.J. and K. W. Clark. 1993. Effects of clipping and nitrogen fertilization on tiller development and flowering in Kentucky Bluegrass. Can. J. Plant Sci. 73:569-575.

Van Haveren, B. P., J. E. Williams, M. L. Pattison, and J. R. Haugh. 1997. Restoring the ecological integrity of public lands. J. Soil Water Conserv. 52:226-231.
Watson, E. R and P. Lapins. 1969. Losses of nitrogen from urine on soils from southwestern Australia. Australian J. Exp. Agr. Animal Husb. 9:85-91.

Weixelman, D., D. Zamudio, K. Zamudio, and K. Heise. 1996. Ecological type identification and ecological status determination. USDA Forest Serv. R4-ECOL-96-01. Ogden, Ut.

Wilson, S. D. and D. Tilman. 1991. Interactive effects of fertilization and disturbance on community structure and resource availability in an old-field plant community. Oecologia 88:61-71.

Wood, S. H. 1975. Holocene stratigraphy and chronology of mountain meadows, Sierra Nevada, Ca. Ph. D. Diss., California Inst. Tech., Pasadena, Calif. Forest. Serv. Region 5, Earth Resource. Monogr.\#4

Woodmansee, R. G. 1978. Additions and losses of nitrogen in grassland ecosystems. Biosc. 28:448-453

Zar, J. H. 1999. Biostatistical analysis ( $4^{\text {th }}$ ed.). Prentice Hall Inc., Upper Saddle River, N.J. 